\title{
Coulisses
}

Revue de théâtre

6 | Printemps 1992

Varia

\section{La Divine Comédie}

\section{(2) OpenEdition}

1 Journals

Édition électronique

URL : http://journals.openedition.org/coulisses/1830

DOI : $10.4000 /$ coulisses. 1830

ISSN : 2546-9460

\section{Éditeur}

Presses universitaires de Franche-Comté

\section{Édition imprimée}

Date de publication : 1 juin 1992

ISSN : 1150-594X

\section{Référence électronique}

"La Divine Comédie », Coulisses [En ligne], 6 | Printemps 1992, mis en ligne le 15 mars 2019, consulté le 23 octobre 2019. URL : http://journals.openedition.org/coulisses/1830 ; DOI : 10.4000/coulisses. 1830

Ce document a été généré automatiquement le 23 octobre 2019.

Coulisses 


\section{La Divine Comédie}

Les 14 et 15 mai 1992, les élèves-comédiens du DUMST 2ème promotion, 1ère année, ont présenté leur travail, au Centre de Rencontres. Il s'agissait d'un spectacle réalisé à partir de La Divine Comédie de Dante, dans une adaptation de Patrick Melior.

\section{Préface de la version dramatique écrite par P. Melior (extraits) :}

«Tout au long de ce travail, nous avons rêvé d'une Divine Comédie "Oratorio ». Au cours du spectacle, nous imaginons un glissement progressif de formes esthétiques: aller du concret à l'abstrait, du relatif à l'absolu, du jeu dramatique à la danse et à la musique. Les mots deviendraient notes d'une partition, les personnages lumières et mouvements. »

«Les personnages - damnés, esprits, diables, âmes, flammes, lumières, visages, voix - ne sont vus qu'une seule fois. Dante et Virgile, puis Dante et Béatrice passent parmi eux. Nous pouvons inverser la perspective. Puisqu'il s'agit d'un récit, Dante peut présenter le «film de son voyage ». Les chœurs successifs défileront devant lui comme devant le spectateur, par permutation circulaire. Autour de Dante et Virgile se métamorphosera l'espace. Ainsi retrouve-t-on le schéma symbolique de la roue et du centre, et le mouvement s'inscrit-il dans une spirale.

Techniquement, cela permet aux danseurs, acteurs, de disparaître et réapparaître dans d'autres chœurs. Que l'on reconnaisse l'un ou l'autre dans divers personnages nous semble intéressant. L'ambiguïté ajoute à la rêverie poétique: n'est-il pas d'âmes qui puissent être à la fois au Paradis et en Enfer ?...

Des chœurs sortiront donc les personnages caractérisés. Dans leurs comportements, ils seront toujours au paroxysme de leur état. Tout silence, tout regard, exigeront une tension absolue. Les personnages ne seront pas abstraits mais surréels. Ils seront formes sublimées de la réalité. C'est une vision hallucinée des mondes que l'on présentera. Chaque silhouette sera celle d'un destin. » 


\section{NOTES}

1. DUMST = Diplôme d'Université "Métiers du Spectacle-Théâtre ", formation assurée par le Centre de Rencontres et l'Université de Franche-Comté. Prochain concours d'entrée : septembre 1993. 